\title{
Food poisoning outbreaks linked to mussels contaminated with okadaic acid and ester dinophysistoxin-3 in France, June 2009
}

V Hossen (virginie.hossen@anses.fr) ${ }^{1}$, N Jourdan-da Silva², Y Guillois-Bécel², J Marchal ${ }^{3}$, S Krys $^{1}$

1. Agence nationale de sécurité sanitaire de l'alimentation, de l'environnement et du travail (ANSES; French Agency for Food, Environmental and Occupational Health), Maisons-Alfort Laboratory for Food Safety (National Reference Laboratory for the control of marine biotoxins), Maisons-Alfort, France

2. Institut de Veille Sanitaire (InVS, National Institute for Public Health Surveillance), Saint Maurice, France

3. General Directorate for Food, Ministry of Agriculture, Paris, France

Citation style for this article:

Hossen V, Jourdan-da Silva N, Guillois-Bécel Y, Marchal J, Krys S. Food poisoning outbreaks linked to mussels contaminated with okadaic acid and ester

dinophysistoxin-3 in France, June 2009.

Euro Surveill. 2011;16(46):pii=20020. Available online: http://www.eurosurveillance.org/ViewArticle.aspx?Articleld=20020

In June 2009, 11 outbreaks of food poisoning occurred in France, involving 45 individuals who had consumed mussels harvested in Vilaine Bay (Northwestern France). Because the toxic dinoflagellate Dinophysis spp. had been detected in the area from mid-May, okadaic acid (OA) and dinophysistoxins were suspected to be the cause of these outbreaks, although the weekly monitoring tests by mouse bioassay had been negative. With the help of the French reporting system for food-borne disease outbreaks, the detailed data on epidemiology, mussel consumption and complete product traceback, were collected for 11 individuals involved in three reported outbreaks. The batch of mussels identified as the source of these three outbreaks contained concentrations of toxins of the okadaic acid group that were approximately eight times higher than the European regulatory limit. Moreover, based on the consumption data available for the 11 cases, a lowest observable adverse effects level (LOAEL) was deduced. The LOAEL calculated from this study, although based on a very limited number of individuals, was in the same range, i.e. approximately $50 \mu \mathrm{g}$ OA equivalents per person, as the LOAEL established by the European Food Safety Authority in 2006.

\section{Introduction}

Diarrhoeic shellfish poisoning (DSP) is a gastrointestinal illness caused by the consumption of shellfish contaminated with algal toxins produced by marine dinoflagellates belonging to the genera Dinophysis spp. (D. fortii, D. mitra, D. rotundata, D. tripos, D. acuta, $D$. norvegica and $D$. acuminata) and Prorocentrum spp. ( $P$. lima, P. maculosum, $P$. concavum, and P. hoffmannianum) $[1,2]$. The DSP toxins, including okadaic acid (OA) and its analogues dinophysistoxin-1 (DTX-1), dinophysistoxin-2 (DTX-2) and dinophysistoxin-3 (DTX-3), belong to the larger group of lipophilic toxins which also includes the azaspiracid, yessotoxin and pectenotoxin group toxins $[3,4]$. Since the discovery of
DSP toxins in the late 1970s, DSP outbreaks have been reported worldwide [5]. To date, documented DSP cases including an exposure estimate, i.e. with consumption and contamination data collected at the same time, remain scarce. To a certain extent, this may be due to underdiagnosis and/or underreporting. Indeed, many consumers suffering from mild gastrointestinal disorders do not consult a physician, and even if they do so, physicians might fail to diagnose DSP, since gastrointestinal symptoms are not specific. In July 2006, the European Commission requested the European Food Safety Authority (EFSA) to issue a scientific opinion assessing the current regulatory limits in the European Union (EU) with regard to human health and analytical methods for marine biotoxins. On 27 November 2007, the EFSA opinion on okadaic acid and its analogues was adopted [6]. Considering the acute toxicity of OA-group toxins, the expert panel on contaminants in the food chain decided to establish an acute reference dose (ARfD), which represents the amount of a substance that can be ingested in a period of 24 hours or less without appreciable health risk. The lowest observable adverse effects level (LOAEL) deduced from available human case reports was used to derive the ARfD. This LOAEL is about $50 \mu \mathrm{g}$ OA equivalents (eq) per person, which approximates to $0.8 \mu \mathrm{g} \mathrm{OA}$ eq/ $\mathrm{kg}$ bodyweight (bw) for a $60 \mathrm{~kg}$ adult. An uncertainty factor of 3 was applied to extrapolate this LOAEL to a no observed adverse effect level (NOAEL). The panel considered that it was not necessary to apply an additional uncertainty factor for the variation among humans as the data were based on observations in several hundreds of affected shellfish consumers, originating from various countries, and considered to account for the most sensitive individuals (i.e. the young children and elderly) $[6,7]$. Finally, the ARfD was calculated by dividing the LOAEL of about $0.8 \mu \mathrm{g} O A \mathrm{eq} / \mathrm{kg}$ bw by the uncertainty factor of 3 ; it resulted in an ARfD of $0.3 \mu \mathrm{g}$ OA eq/ $\mathrm{kg}$ bw. Based on the ARfD, and assuming that this amount of 
toxin could be contained in a single large portion of shellfish of $400 \mathrm{~g}$, EFSA advised that a concentration of $45 \mu \mathrm{g} \mathrm{OA} \mathrm{eq/kg} \mathrm{shellfish} \mathrm{flesh} \mathrm{would} \mathrm{not} \mathrm{result} \mathrm{in}$ risks to the consumer, whereas the EU limit is currently at $160 \mu \mathrm{g} \mathrm{OA} \mathrm{eq/kg} \mathrm{shellfish} \mathrm{flesh} \mathrm{[8].}$

The Panel noted however that information on the doses and profiles of OA-related toxins provided in the majority of reports on DSP outbreaks is very limited. Indeed, the toxin concentrations cannot be unequivocally established, particularly if the tested shellfish are not from the same batch as those consumed. Moreover, these studies rarely provide precise information on the amount of contaminated shellfish that has been consumed by intoxicated people.

In June 2009, 11 DSP outbreaks were reported in France within a few days (from 3 to 9 June), involving 45 individuals who had consumed mussels. Following EFSA recommendations for detailed reports on shellfish consumption and collection of reliable data on toxin content in the event of DSP outbreaks [6], a thorough investigation of human cases was conducted with the help of the stakeholders involved in the French reporting system for food-borne disease outbreaks. Data on epidemiology, mussel consumption, complete product traceback and toxin content of the suspected mussel batch were examined for three of the 11 outbreaks. The aim of our study was to establish a dose-response relationship by calculating the LOAEL from this case study and to compare it to the one previously established by EFSA in 2006 [6].

\section{Methods}

Food poisoning outbreaks associated with mussels: reporting and investigation

Notification of food-borne outbreaks has been mandatory in France since 1987 [9]. Food poisoning outbreaks are notified to the regional public health authority and to the regional veterinary services and forwarded to the Health Emergency Mission of the Ministry of Agriculture. The regional veterinary services (Direction Départementale de la Protection des Populations, DDPP) are in charge of carrying out the food traceback investigation, withdrawing the incriminated food from the market and destroying the contaminated food. When shellfish are suspected of being contaminated, a sample is sent to the national reference laboratory (NRL) for the control of marine biotoxins of MaisonsAlfort for analysis. Regional veterinary services report the results of their investigations to the regional public health authorities which depend on the Ministry of Health. The Ministry of Health, with support from the regional offices of the National Institute for Public Health Surveillance (InVS), is in charge of the epidemiological investigation (see Figure 1).

An outbreak is defined as an incident in which two or more cases had shared a common meal. For this investigation, the meal should include mussels. A case was defined as a patient with diarrhoea, i.e. at least three liquid stools in a day after having consumed mussels, in the period from 1 to 15 June 2009.

Data relating to the number of cases, onset dates, symptom identification, symptom severity and recovery time were collected through interviews of cases and exposed persons. On request of our laboratory, since our intention was to deduce a LOAEL from the outbreak cases, the quantity of mussels consumed and also personal information (sex, age and weight) of the affected persons were added to the standard questionnaire.

\section{Analysis of lipophilic toxins (okadaic acid and dinophysistoxins)}

A $10 \mathrm{~kg}$ shellfish sample from the same batch as the one suspected to be involved in three outbreaks was collected by the DDPP of the département Morbihan and sent to NRL for the control of marine biotoxins of Maisons-Alfort for analysis of lipophilic toxins. A homogenate of the digestive glands of mussels was analysed by the mouse bioassay (MBA) described by Yasumoto et al. [3] to determine DSP toxicity according to EU Regulation 2074/2005/EC [10]. The MBA measures the total toxicity based on the biological response of the animals to the toxins. In order to determine the toxin profile of the sample, an in-house liquid chromatography-tandem mass spectrometry (LC-MS/MS) validated test, based on a method developed by McKenzie et al. [11] and further adapted by the European Union Reference Laboratory [12], was used as an additional test to investigate these outbreaks. The LC-MS/MS analysis specifically detects, identifies and quantifies $\mathrm{OA}$ and its dinophysistoxins, as well as other lipophilic toxin groups for which a toxin standard per group is available (i.e. pectenotoxins, azaspiracids, yessotoxins, gymnodimine, spirolides). It became the reference method in the EU on 1 July 2011 [13].

\section{Results}

From 1 to 9 June 2009, 11 outbreaks involving a total of 45 individuals were reported through the food-borne outbreak reporting system in three départements of western France: Morbihan, Loire Atlantique and Gironde (Figure 2).

The investigation revealed that all of the intoxicated people had consumed mussels harvested from one production area (Vilaine bay) located in Morbihan, Brittany, between 29 May and 3 June 2009. They suffered from diarrhoea, i.e. at least three liquid stools in a day, in some cases accompanied with abdominal cramps, as well as nausea and vomiting. In one case, fever $\left(337^{\circ} \mathrm{C}\right)$ was also reported. The onset of symptoms ranged from three to 20 hours after consuming the mussels and recovery time was one to four days (Table 1).

Detailed investigation of Outbreaks 1,2 and 3 Shellfish traceback

The traceback investigation showed that Outbreaks 1,2 and 3 , involving at least 18 individuals in the 
département Morbihan, were linked to a single batch of mussels from the Vilaine Bay. In this bay, a high risk period for Dinophysis has been defined between May and August [14]. During this period, both water and shellfish are sampled on a weekly basis, i.e. each Monday or Tuesday depending on the tide, at five predefined sampling points for shellfish and six points for water. The MBA results are available by the end of the week, on Thursday or Friday, and communicated without delay to the local authorities for a decision on whether to open or close the harvesting areas. The harvested mussels incriminated in the three outbreaks came from an area where the presence of toxic dinoflagellates Dinophysis spp. was detected from mid-May during the routine phytoplankton monitoring, but the weekly MBA were negative. Thus, the area remained open when $210 \mathrm{~kg}$ of mussels were harvested on 1 June. Shellfish harvesting in the area was suspended on 3 June when the outbreaks became known. On 4 June, the area was closed when the MBA result from that week showed a positive result. The distribution of the contaminated batch of mussels is described in Figure 3. The batch of $210 \mathrm{~kg}$ was separated into two parts: $10 \mathrm{~kg}$ were sold to a family (Outbreak 1) and 200 $\mathrm{kg}$ were sold to a dispatch centre. Of these $200 \mathrm{~kg}, 50$ kg were sold to Restaurant A (Outbreak 2), $40 \mathrm{~kg}$ were sold to a family (Outbreak 3 ) and $10 \mathrm{~kg}$ were sold to Restaurant B. After notification of the outbreaks, the dispatch centre destroyed the remaining $100 \mathrm{~kg}$. The $10 \mathrm{~kg}$ sample distributed to Restaurant B was not consumed and was sent to the NRL for the control of marine biotoxins of Maisons-Alfort for analysis. As the presence of toxic dinoflagellate Dinophysis spp. in the water had been detected during the routine phytoplankton monitoring, the sample was initially screened for $\mathrm{OA}$ and dinophysistoxins.

Epidemiological and consumption data

The detailed results of the epidemiological investigation are summarised in Table 2. Information on the number of cases, including sex, age and weight, symptom onset, reported symptoms and recovery time were available for 13 of the 18 ill individuals of Outbreaks 1 , 2 and 3.

The age of the cases ranged from 11 to 65 years (mean age: 39.5 years) and their weights ranged from 38 to $95 \mathrm{~kg}$ (mean weight: $63 \mathrm{~kg}$ ). The mean weight observed in this case study was close to the $60 \mathrm{~kg}$ body weight frequently used in risk assessment studies. Most of

\section{FIGURE 1}

Reporting system for food poisoning outbreaks in France

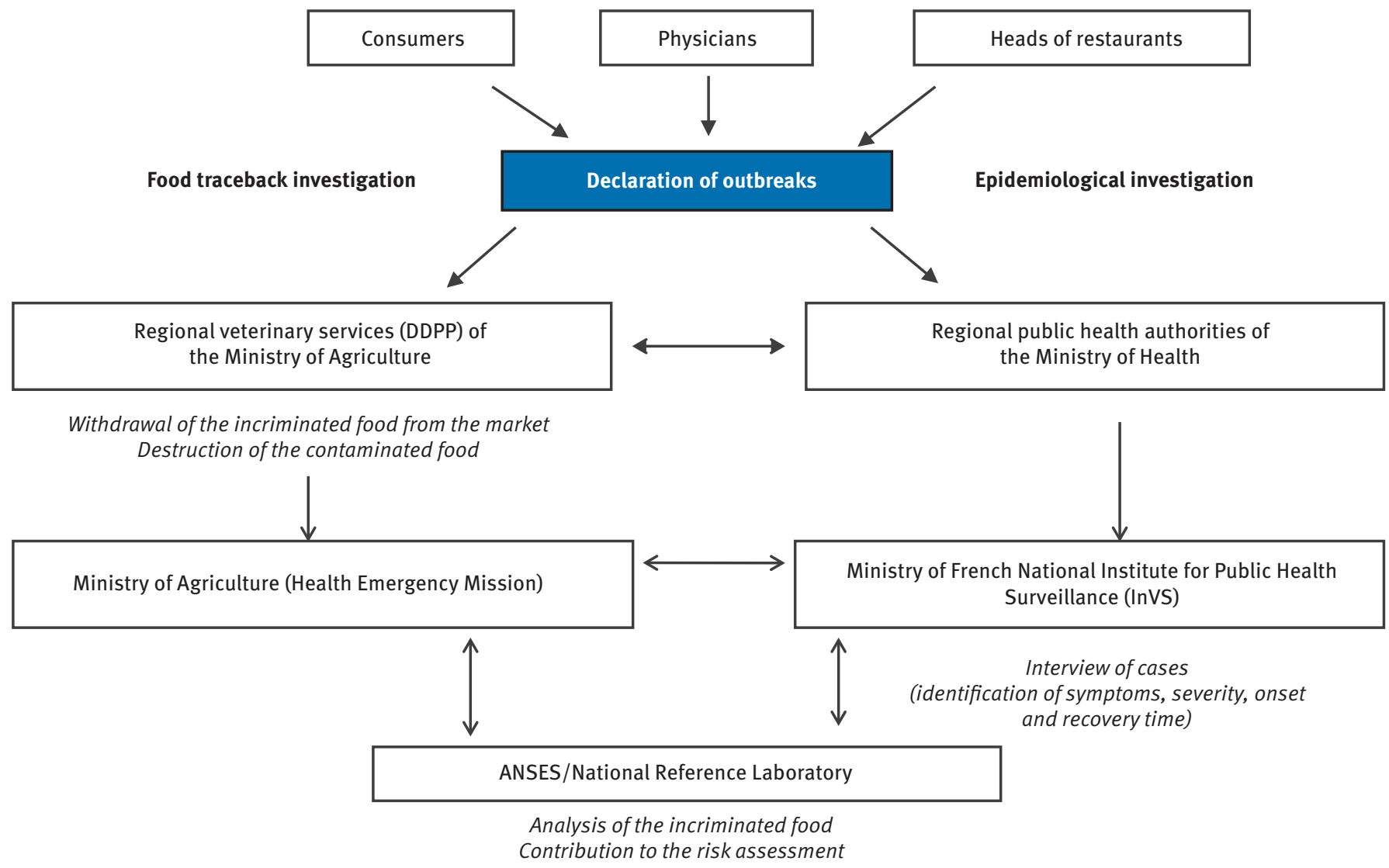


the intoxicated individuals were women $(9 / 13)$. The reported symptoms included abdominal cramps and diarrhoea (13/13), nausea (8/13), vomiting (5/13) and fever (1/13). The symptoms occurred between three and 15 hours after shellfish consumption. In most cases, symptoms resolved one to four days after

\section{FIGURE 2}

Geographic distribution of mussel food poisoning outbreaks and reported cases, France, June 2009 (n=45 cases)

Number of outbreaks / reported cases per département of residence

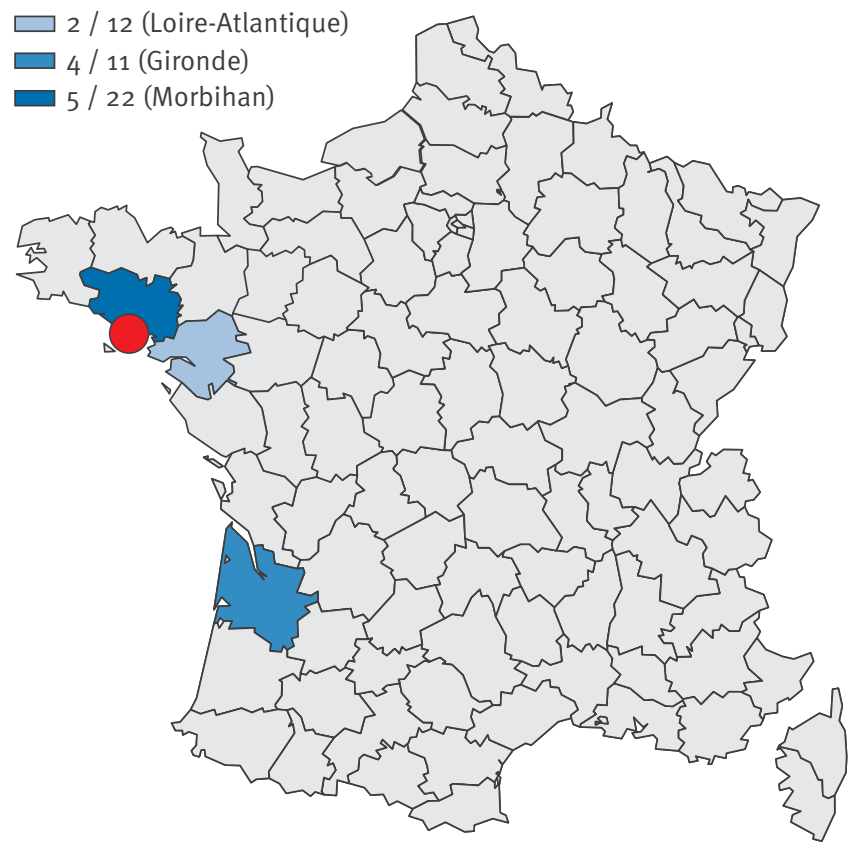

The red circle indicates the area where contaminated mussels were harvested. consumption. None of the people were hospitalised. Quantities of mussel consumption were reported for 11 of 18 individuals, with the reported amounts varying from 150 to $900 \mathrm{~g}$.

\section{Content of lipophilic toxins in the}

suspected batch of mussels

The sample of mussels from the batch suspected to be involved in Outbreaks 1, 2 and 3 (Table 2) tested positive in the MBA indicating the presence of DSP toxins at a concentration higher than the regulatory limit of 160 $\mu \mathrm{g} O A \mathrm{eq} / \mathrm{kg}$ shellfish flesh. The three mice tested died respectively in 47, 49 and 56 minutes. They exhibited symptoms typical of the OA group of toxins i.e. apathy, general weakness, difficulty to move, spasms, respiratory distress and death. The analysis of the sample by the informative LC-MS/MS method showed that it contained $681 \mu \mathrm{g}$ of free $\mathrm{OA} / \mathrm{kg}$ and $580 \mu \mathrm{g}$ of DTX-3/ $\mathrm{kg}$. Hydrolysis of DTX 3 toxins (esterified forms of parent toxins, which can be OA, DTX 1 or DTX 2 ) gave free $O A$ only. As indicated in the scientific opinion document by EFSA, the toxicity equivalence factor (TEF) values for DTX 3 are equal to those of the corresponding unesterified toxins [6]. Consequently, the total concentration of OA was calculated at 1,261 $\mathrm{gg} \mathrm{OA}$ eq/ $\mathrm{kg}$ shellfish flesh, which is approximately eight times higher than the European regulatory limit for OA group toxins. This high concentration explains the very short survival time of the mice and the rapid appearance of the symptoms following the consumption of the mussels by those who had been intoxicated.

\section{Discussion}

From 1 to 9 June 2009, 11 DSP outbreaks involving a total of 45 individuals were reported. In comparison, a single DSP outbreak involving two individuals was confirmed in 2006, seven outbreaks involving 109 individuals in

\section{TABLE 1}

Epidemiological data of reported disease outbreaks associated with the consumption of mussels harvested in Vilaine bay, France, June 2009 ( $n=45$ cases)

\begin{tabular}{|c|c|c|c|c|c|c|}
\hline Outbreak & Département & $\begin{array}{l}\text { Number of individuals } \\
\text { ill/exposed }\end{array}$ & Date of meal & Symptoms & $\begin{array}{l}\text { Time between meal and approx. } \\
\text { symptom onset }\end{array}$ & Recovery time \\
\hline $1^{\mathrm{a}}$ & Morbihan & $3 / 3$ & 1 Jun 2009 & $A C, D$ & $12-15 \mathrm{~h}$ & $1-3$ days \\
\hline $2^{\mathrm{a}}$ & Morbihan & $7 / 7$ & 1 Jun 2009 & $\mathrm{~N}, \mathrm{AC}, \mathrm{V}, \mathrm{D}, \mathrm{F}$ & $6-10 \mathrm{~h}$ & 2-4 days \\
\hline $3^{\mathrm{a}}$ & Morbihan & at least $8 / \mathrm{UNK}^{\mathrm{b}}$ & 2 Jun 2009 & $\mathrm{~N}, \mathrm{AC}, \mathrm{D}$ & $3-13 \mathrm{~h}$ & 1 day \\
\hline 4 & Morbihan & $2 / 2$ & 5 Jun 2009 & $\mathrm{~N}, \mathrm{~V}, \mathrm{AC}, \mathrm{D}$ & $8-20 \mathrm{~h}$ & at least 3 days \\
\hline 5 & Morbihan & $2 / 2$ & 5 Jun 2009 & UNK & UNK & UNK \\
\hline 6 & Gironde & $3 / 7$ & 3 Jun 2009 & $\mathrm{D}$ & $4-16 \mathrm{~h}$ & UNK \\
\hline 7 & Gironde & $3 / 3$ & 4 Jun 2009 & $\mathrm{D}$ & $4 \mathrm{~h}$ & 2 days \\
\hline 8 & Gironde & $2 / 2$ & 4 Jun 2009 & V, D & 4-12 h & UNK \\
\hline 9 & Gironde & $3 / 3$ & 5 Jun 2009 & V, D & $8 \mathrm{~h}$ & UNK \\
\hline 10 & Loire-Atlantique & $10 / 10$ & 1 Jun 2009 & V, D & UNK & UNK \\
\hline 11 & Loire-Atlantique & $2 / 2$ & 3 Jun 2009 & UNK & UNK & UNK \\
\hline
\end{tabular}

AC: abdominal cramps, D: diarrhoea, N: nausea, V: vomiting, UNK: unknown.

a Outbreaks 1, 2 and 3 are described in full detail in Table 2.

b This outbreak occurred in a restaurant. The owner was informed that eight people fell ill after consuming mussels, only three of whom reported the intoxication to their physician. The total number of people who consumed the contaminated mussels is not known; consequently, the number of ill individuals may be underestimated. 
2007, and none in 2008 [15]. These outbreaks had been caused either by French mussels contaminated with $\mathrm{OA}$ group toxins or by Irish mussels contaminated with azaspiracides. As was the case in June 2009, most of these earlier DSP outbreaks occurred within a period of a few days because the regional veterinary services of the Ministry of Agriculture had withdrawn the incriminated food from the market and closed the production area following the results of the traceback investigation. If the shellfish are exchanged or exported, the Health Emergency Mission of the Ministry of Agriculture immediately notifies the European Commission using the Rapid Alert System for Food and Feed (RASFF). The goal of the notification is to give all RASFF members the information so that they can confirm whether the product in question is on their market and take the necessary measures. In the case of the DSP outbreaks in June 2009, no RASFF alert was issued since the contaminated shellfish were only distributed on French territory. The production area was closed by prefectoral order on 3 June when the first three outbreaks were reported, and the suppliers and consumers were informed immediately in order to withdraw and/or recall the unconsumed shellfish.

The described outbreaks were the result of an unusually rapid shellfish contamination, occurring within one week in which Dinophysis density increased by a factor

\section{FIGURE 3}

Distribution of the batch of mussels involved in three outbreaks of diarrhoeic shellfish poisoning, France, June 2009

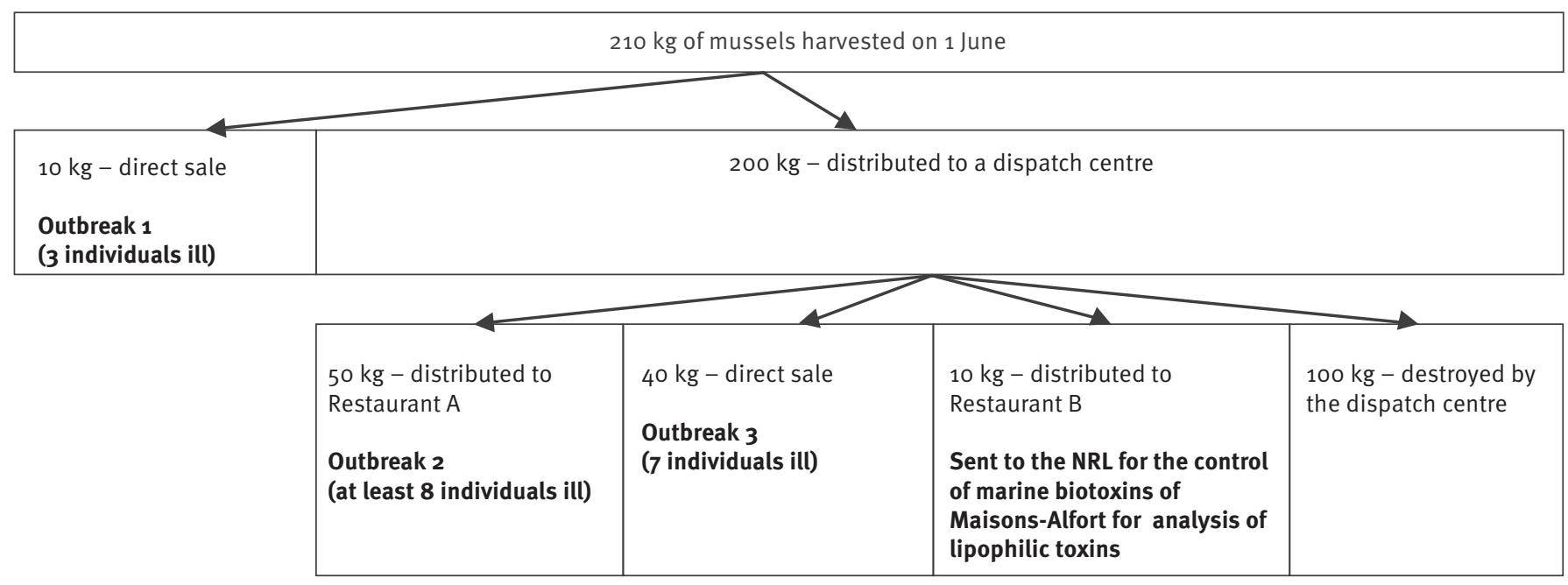

NRL: national reference laboratory

TABLE 2

Epidemiological and consumption data in three outbreaks of diarrhoeic shellfish poisoning, France, June 2009 (n=18 cases)

\begin{tabular}{|c|c|c|c|c|c|c|}
\hline Outbreak & $\begin{array}{c}\text { Date of } \\
\text { consumption }\end{array}$ & $\begin{array}{l}\text { Number of individuals } \\
\text { ill/exposed and sex and age } \\
\text { of the ill (in ascending order) }\end{array}$ & $\begin{array}{l}\text { Weight of the } \\
\text { intoxicated person }\end{array}$ & $\begin{array}{l}\text { Quantity of mussels } \\
\text { consumed (weight } \\
\text { including shell) }\end{array}$ & Symptoms & $\begin{array}{l}\text { Approx. symptom } \\
\text { onset/ recovery time }\end{array}$ \\
\hline \multirow{3}{*}{1} & \multirow{3}{*}{1 June 2009} & \multirow{3}{*}{$\begin{array}{c}3 / 3 \\
1 \text { male, } 2 \text { female } \\
32,35 \text {, and } 55 \text { years-old }\end{array}$} & $59 \mathrm{~kg}$ & $400 \mathrm{~g}$ & $A C, D$ & $15 \mathrm{~h} / 1$ day \\
\hline & & & $64 \mathrm{~kg}$ & $400 \mathrm{~g}$ & AC, D & $12 \mathrm{~h} / 3$ days \\
\hline & & & $70 \mathrm{~kg}$ & $400 \mathrm{~g}$ & AC, D & $12 \mathrm{~h} / 3$ days \\
\hline \multirow{7}{*}{2} & \multirow{7}{*}{1 June 2009} & \multirow{7}{*}{$\begin{array}{c}7 / 7 \\
3 \text { male, } 4 \text { female } \\
18,39,40,63 \text {, and } 65 \\
\text { years-old }\end{array}$} & $90 \mathrm{~kg}$ & $600-700 \mathrm{~g}$ & $\mathrm{~N}, \mathrm{~V}, \mathrm{AC}, \mathrm{D}$ & $6 \mathrm{~h} / 3$ days \\
\hline & & & $58 \mathrm{~kg}$ & $700 \mathrm{~g}$ & $\mathrm{~N}, \mathrm{~V}, \mathrm{AC}, \mathrm{D}$ & $6 \mathrm{~h} / 3$ days \\
\hline & & & $67 \mathrm{~kg}$ & ca. $900 \mathrm{~g}$ & $\mathrm{~N}, \mathrm{~V}, \mathrm{AC}, \mathrm{D}$ & $6 \mathrm{~h} / 4$ days \\
\hline & & & $58 \mathrm{~kg}$ & ca. $150 \mathrm{~g}$ & $\mathrm{~N}, \mathrm{~V}, \mathrm{AC}, \mathrm{D}$ & 6-7h / 2 days \\
\hline & & & $48 \mathrm{~kg}$ & $\mathrm{ca} .400 \mathrm{~g}$ & AC, D & 6-10h / UNK \\
\hline & & & $61 \mathrm{~kg}$ & ca. $900 \mathrm{~g}$ & $\mathrm{~N}, \mathrm{~V}, \mathrm{AC}, \mathrm{D}, \mathrm{F}$ & 6-7h / 3 days \\
\hline & & & $38 \mathrm{~kg}$ & ca. $150 \mathrm{~g}$ & $\mathrm{~N}, \mathrm{AC}, \mathrm{D}$ & 6-7h / UNK \\
\hline \multirow{3}{*}{3} & \multirow{3}{*}{2 June 2009} & \multirow{3}{*}{$\begin{array}{c}\text { at least } 8 / \text { UNK } \\
3 \text { female } \\
28,39 \text {, and } 62 \text { years-old }\end{array}$} & $58 \mathrm{~kg}$ & ca. $900 \mathrm{~g}$ & $\mathrm{~N}, \mathrm{AC}, \mathrm{D}$ & 3h / 1 day \\
\hline & & & $95 \mathrm{~kg}$ & UNK & AC, D & 4h / 1 day \\
\hline & & & $58 \mathrm{~kg}$ & UNK & $\mathrm{N}, \mathrm{AC}, \mathrm{D}$ & 13h / 1 day \\
\hline
\end{tabular}

AC: abdominal cramps, D: diarrhoea, F: fever $\left(337^{\circ} \mathrm{C}\right), \mathrm{N}$ : nausea, UNK: unknown, V: vomiting. 
of 5 in the harvesting area, quickly contaminating the mussels with a high toxin level. At the time of the outbreaks, the MBA was used for monitoring DSP toxins in shellfish; the result of the weekly test performed on the mussel sample harvested on 25 May was found negative on 29 May, whereas the result of the test on sample harvested on 1 June was found positive on 4 June. The occurrence of these outbreaks demonstrates that even if an efficient monitoring system is in place, rapid shellfish contamination may appear suddenly and cause health problems. The following factors could be responsible for the failure of the monitoring system to detect the contamination: the level of contamination of the sample harvested on 25 May may not have been representative of the contamination within the production area due to heterogeneity, and the MBA may have suffered from a lack of sensitivity for this sample [6]. This sudden toxic event could have been prevented by increasing the frequency of the sampling and/or the number of sampling points and/or by a quantitative method to follow the increase of the toxins content in shellfish. The implementation of the LC-MS/ MS method as the reference method for monitoring lipophilic toxins [11] will make such quantification possible, and preventive actions can be taken to avoid the harvesting of shellfish in areas where a toxic episode is likely to occur.

Information in reports of DSP outbreaks rarely provide data on the actual quantities of toxin ingested by the intoxicated individuals since the tested shellfish samples often come from a batch different from the one consumed. Based on the concentration and consumption data detailed here, the minimum amount of $O A$ causing symptoms was estimated for 11 intoxicated individuals involved in three of the 11 reported outbreaks. It was possible to deduce a LOAEL from this study. The $10 \mathrm{~kg}$ of mussels, from the same batch as the one involved in the three outbreaks, represented $2.4 \mathrm{~kg}$ of raw flesh, thus the flesh/whole shellfish ratio was estimated to be $24 \%$. Although the flesh ratio varies from batch to batch, the value of $24 \%$ is consistent with information released by the Food Safety Authority of Ireland (18$24 \%$ ) and the Food and Agriculture Organization of the United Nations $(24 \%)[16,17]$.

In the outbreaks described here, the portion size ranged from 150 to $900 \mathrm{~g}$ of mussels, which translates to 36 to $216 \mathrm{~g}$ of mussel flesh. This is consistent with the data provided by the EU Member States to EFSA and the information included in EFSA's comprehensive database indicating that a portion size of $400 \mathrm{~g}$ of shellfish flesh has been identified as an appropriate estimate of a large portion [18].

Given that the toxin concentration in the incriminated batch was $1,261 \mu \mathrm{g} O A \mathrm{eq} / \mathrm{kg}$ mussel flesh and that DSP symptoms were observed after consuming 36 to $216 \mathrm{~g}$ of mussel flesh, the toxin intake inducing symptoms in the intoxicated individuals ranged from 45 to $272 \mu \mathrm{g} \mathrm{OA}$ eq. The lowest toxin intake referred to two persons with a bodyweight of 38 and $58 \mathrm{~kg}$, respectively. It corresponds to $1.2 \mu \mathrm{g}$ and $0.8 \mu \mathrm{g} \mathrm{OA}$ eq $/ \mathrm{kg}$ bw, respectively. Therefore, the LOAEL deduced from our study was $45 \mu \mathrm{g} \mathrm{OA} \mathrm{eq/person} \mathrm{or} 0.8 \mu \mathrm{g} \mathrm{OA} \mathrm{eq/kg}$ bw for the most sensitive person.

Finally, the data collected in our study, although based on a limited number of individuals, support the LOAEL for human illness of approximately $50 \mu \mathrm{g} \mathrm{OA} \mathrm{eq/person}$ or $0.8 \mu \mathrm{g} \mathrm{OA} \mathrm{eq/kg} \mathrm{bw} \mathrm{for} \mathrm{a} 60 \mathrm{~kg}$ adult established by the EFSA in 2006 [6].

\section{Acknowledgments}

The authors would like to thank M. Retho from IFREMER at La Trinité sur Mer for providing information on the phytoplankton and phycotoxin monitoring plan in the Vilaine Bay area, and C. Alves and P. Leroy from the national reference laboratory for the control of marine biotoxins of Maisons-Alfort for their skillful technical assistance.

\section{References}

1. Vale P. Chemistry of diarrhetic shellfish poisoning toxins. In: Botana LM, editor. Phycotoxins: chemistry and biochemistry. Oxford: Blackwell Publishing; 2007. p. 211-21.

2. Van Dolah F. Diversity of marine and freshwater algal toxins. In: Botana LM, editor. Seafood and freshwater toxins: pharmacology, physiology and detection. New York: Marcel Dekker; 2000. p. 19-43.

3. Yasumoto T, Murata M, Oshima Y, Matsumoto GK, Clardy I. Diarrhetic shellfish poisoning. In: Ragelis E, editor. Seafood toxins. ACS symposium series, 262. Washington DC: American Chemical Society; 1984. p. 207-214.

4. Kumagai M, Yanagi T, Murata M, Yasumoto T, Kat M, Lassus P, et al. Okadaic acid as the causative toxin of diarrhetic shellfish poisoning in Europe. Agric Biol Chem. 1986;50(11):2853-7.

5. Economou V, Papadopoulou C, Brett M, Kansouzidou A, Charalabopoulos K, Filioussis G, et al. Diarrheic shellfish poisoning due to toxic mussel consumption: the first recorded outbreak in Greece. Food Addit Contam. 2007;24(3):297-305.

6. Opinion of the Scientific Panel on Contaminants in the Food chain on a request from the European Commission on marine biotoxins in shellfish - okadaic acid and analogues. EFSA Journal. 2008;589:1-62. Available from: http://www.efsa. europa.eu/en/scdocs/doc/589.pdf

7. Benford D, Eskola M, Van Leeuwen R, European risk assessments of marine biotoxins. Proceedings of the seventh international conference on molluscan shellfish safety. Nantes, France, 14-19 Jun 2009. p. 198-202. Available from: http:// www.symposcience.org/exl-doc/colloque/ART-00002539.pdf

8. Regulation (EC) No 853/2004 of the European Parliament and of the Council of 29 April 2004 laying down specific hygiene rules for food of animal origin. Official Journal of the European Union. Luxembourg: Publications Office of the European Union. 25.6.2004: L 226/22. Available from http://eur-lex.europa.eu/ LexUriServ/LexUriServ.do?uri=0J:L:2004:226:0022:0082:EN: PDF

9. Ministère de l'agriculture, de l'alimentation, de la pêche, de la ruralité et de l'aménagement du territoire. Modification de la note de service DGAL/MUS/N2009-8191 du 9 juillet 2009 relative à la gestion des toxi-infections alimentaires collectives - Déclaration, inspection et rapport d'investigation [Changing the memo DGAL/MUS/N2009-8191 of 9 July 2009 relating to the management of collective food poisoning due to infections or toxins- Declaration, inspection and investigation report]. Note de service DGAL/MUS/N2011-8002. 3 Jan 2011. French. Available from: http://agriculture.gouv.fr/IMG/pdf/ DGALN20118002Z.pdf

10. European Commission. Commission Regulation (EC) No 2074/2005 of 5 December 2005 laying down implementing measures for certain products under Regulation (EC) No $853 / 2004$ of the European Parliament and of the Council and for the organisation of official controls under Regulation (EC) No 854/2004 of the European Parliament and of the Council and Regulation (EC) No 882/2004 of the European Parliament and of the Council, derogating from Regulation (EC) No 852/2004 of the European Parliament and of the Council 
and amending Regulations (EC) No $853 / 2004$ and (EC) No 854/2004. Official Journal of the European Union. Luxembourg: Publications Office of the European Union. 22.12.2005.:L 338/27. Available from: http://eur-lex.europa.eu/LexUriServ/ LexUriServ.do?uri=0J:L:2005:338:0027:0059:EN:PDF

11. MacKenzie L, Holland P, McNabb P, Beuzenberg V, Selwood A, Suzuki T. Complex toxin profiles in phytoplankton and Greenshell mussels (Perna canaliculus), revealed by LC-MS/MS analysis. Toxicon, 2002;40(9):1321-30.

12. Community Reference Laboratory for Marine Biotoxins (CRL-MB). EU-harmonised standard operating procedure for determination of OA-group toxins by LC-MS/MS. Version 1, August 2009. Vigo: CRL-MB, Available from: http://www.aesan. msps.es/CRLMB/docs/docs/procedimientos/EU-HarmonisedSOP-LCMS-OA-Version1.pdf

13. European Commission. Commission Regulation (EU) No 15/2011 of 10 January 2011 amending Regulation (EC) No 2074/2005 as regards recognised testing methods for detecting marine biotoxins in live bivalve molluscs. Official Journal of the European Union. Luxembourg: Publications Office of the European Union. 11.1.2011: L 6/3.Available from: http://eur-lex. europa.eu/LexUriServ/LexUriServ.do?uri=0J:L:2011:006:0003: 0006:EN:PDF

14. Belin C, Dreves L, Marchand M. Document de prescription, Cahier de procédures et de programmation REPHY 2009 [Prescription document, Specifications on procedures and programming for the Phytoplankton and Phycotoxin Monitoring Network]. Institut français de recherche pour l'exploitation de la mer (IFREMER). French. [Accessed 26 May 2009]. Available from: http://envlit.ifremer.fr/content/ download/27364/222243/

15. Delmas G, Jourdan da Silva N, Pihier N, Weill FX, Vaillant V, de Valk H. Les toxi-infections alimentaires collectives en France entre 2006 et 2008 [Foodborne outbreaks in France between 2006 and 2008]. Bulletin Epidémiologique Hebdomadaire. 2010;31-32:344-348. French. Available from: http://www.invs. sante.fr/beh/2010/31_32/beh_31_32_2010.pdf

16. Committee on Toxicity of Chemicals in Food Consumer Products and the Environment (COT). COT Statement on risk assessment of marine biotoxins of the okadaic acid, pectenotoxin, azaspiracid and yesstoxin groups in support of human health, COT statement 2006/16, December 2006. London: COT. Available from: http://www.food.gov.uk/multimedia/pdfs/ cotstatementlipophilic200616.pdf

17. Food and Agriculture Organization of the United Nations (FAO). FAO fisheries technical paper no. 309: Yield and nutritional value of the commercially more important fish species. 1989. Rome: FAO. [Accessed 1 Feb 2011]. Available from: http://www. fao.org/DOCREP/003/To219E/To219Eoo.HTM

18. EFSA Panel on Contaminants in the Food Chain (CONTAM); Statement on further elaboration of the consumption figure of $400 \mathrm{~g}$ shellfish meat on the basis of new consumption data. EFSA Journal. 2010;8(8):1706. Available from: http://www.efsa. europa.eu/en/efsajournal/doc/1706.pdf 